\title{
METHYLPHENIDATE: A REVIEW
}

\section{REVIEW ARTICLE}

OLIVEIRA, Vinicius Faustino Lima de ${ }^{1}$, MOREIRA, Danilo José Silva², FONSECA, Juliana Brito $\mathrm{da}^{3}$, ROSSI, Karoline ${ }^{4}$, VASCONCELOS, Suzana dos Santos ${ }^{5}$, DIAS, Claudio Alberto Gellis de Mattos $^{6}$, OLIVEIRA, Euzébio de ${ }^{7}$, DENDASCK, Carla Viana ${ }^{8}$, ARAÚJO, Maria Helena Mendonça de ${ }^{9}$, FECURY, Amanda Alves ${ }^{10}$

OLIVEIRA, Vinicius Faustino Lima de. Et al. Methylphenidate: a review. Revista Científica Multidisciplinar Núcleo do Conhecimento. Year 06, Ed. 05, Vol. 01, pp. 0514. May 2021. ISSN: 2448-0959, Access Link: https://www.nucleodoconhecimento.com.br/health/methylphenidate-a-review, DOI: 10.32749/nucleodoconhecimento.com.br/health/methylphenidate-a-review

\section{SUMMARY}

Methylphenidate (MFD) is an amphetamine-derived medicine that stimulates the Central Nervous System (CNS), promoting increased attention, less distraction and increased sense of motivation. This study aims to describe the main pharmaceutical characteristics of MFD, highlight the clinical indications for the use of MFD and detail

\footnotetext{
${ }^{1}$ Medical scholar. Federal University of Amapá (UNIFAP).

${ }^{2}$ Medical scholar. Federal University of Amapá (UNIFAP).

${ }^{3}$ Medical academic. Federal University of Amapá (UNIFAP).

${ }^{4}$ Medical academic. Federal University of Amapá (UNIFAP).

${ }^{5}$ Medical academic. Federal University of Amapá (UNIFAP).

${ }^{6}$ Biologist, PhD in Theory and Behavior Research, Professor and researcher of the Chemistry Degree Course of the Institute of Basic, Technical and Technological Education of Amapá (IFAP) and the Graduate Program in Professional and Technological Education (PROFEPT IFAP).

${ }^{7}$ Biologist, PhD in Tropical Diseases, Professor and researcher of the Physical Education Course, Federal University of Pará (UFPA).

${ }^{8}$ Theologian, PhD in Clinical Psychoanalysis. She has been working for 15 years with Scientific Methodology (Research Method) in Scientific Production Guidance for Masters and Doctoral Students. Specialist in Market Research and Health Research. Doctoral Student in Communication and Semiotics (PUC SP).

${ }^{9}$ Doctor, Master in Teaching and Health Sciences, Professor and researcher of the Medical Course of Macapá Campus, Federal University of Amapá (UNIFAP).

${ }^{10}$ Biomedical, PhD in Tropical Diseases, Professor and researcher of the Medical Course of Macapá Campus, Federal University of Amapá (UNIFAP), Pro-Rector of Research and Graduate Studies (PROPESPG) of the Federal University of Amapá (UNIFAP).
}

$\mathrm{RC}: 84390$

Link di accesso: https://www.nucleodoconhecimento.com.br/salute/metilfenidato-una- 
the possible adverse events arising from the consumption of MFD. For this, we conducted a research in the databases ScienceResearch.com, SciELO, LILACS, PubMed and EMBASE and in the institutional repositories of the Federal University of São Paulo, Federal University of Minas Gerais and Federal University of Ceará, using the keywords and associations "methylphenidate", "ritalin", "effects" and "effects". It was evidenced that the drug consists of a racemic mixture formed by four stereoisomers, and the pharmacologically active compound is racemate dextrogyl (d,I)treo-MFD. It acts on the blockade of dopamine and norepinephrine transporters from the CNS, promoting effects that justify its prescription to treat Attention Deficit Hyperactivity Disorder (ADHD). In recent years, its consumption for non-therapeutic purposes has increased. Some adverse effects of its use have been reported, and insomnia, irritability and headache have been reported.

Keywords: Methylphenidate, Dopamine, Norepinephrine.

\section{INTRODUCTION}

Methylphenidate (MFD) is a central nervous system (CNS) stimulator from piperidine, a type of amphetamine (PAPA, 2013). The MFD has a higher consumption than the sum of all other psychostimulants, being the most consumed in the world (SALVIANO, 2015).

In the early 1990s, on a global scale, 2.8 tons of MFD were produced. In 2000, this value was raised to 16 tons and, ten years later, the statistical mark reached 43 tons. In Brazil in 2011, $413 \mathrm{~kg}$ of MFD (CALIMAN; DOMITROVIC, 2013).

It is prescribed for individuals diagnosed with Attention Deficit Hyperactivity Disorder (ADHD) and for narcolepsy (CALDEIRA, 2015). In Brazil, MFD is available to be marketed under the names Ritalina $\AA$, Ritalina $L A \circledast$ and Concerta $\AA$, all with oral intake. The MFD release dynamics in the body have immediate and slow action options, such as Ritalin $\circledast$ which has immediate effect, while Ritalin $L A \circledast$ and Concerta ${ }^{\circledR}$ present longacting formulas (BATISTA, 2015). 
When starting treatment with MFD, the doses indicated to infant patients range from 5 to $20 \mathrm{mg} /$ day, with possible adjustments, and increments can be made up to the maximum daily dose of $60 \mathrm{mg} /$ day. Another option for determining the daily dose is starting with two daily intake of $0.3 \mathrm{mg} / \mathrm{kg}$ and, according to the need of the case, an increase of $0.1 \mathrm{mg} / \mathrm{kg} /$ dose can be made weekly and should not exceed $2 \mathrm{mg} / \mathrm{kg} /$ day. Due to the lack of studies directed at children under 6 years of age, the use of MFD in this population is not indicated. In adults, the daily dose of MFD ranges from 10 to 72mg (FARIA, 2017).

The MFD provides increased attention, resulting in less distraction, and increased sense of motivation, leading to interest in achieving goals and actions (CÂNDIDO, 2018). In Brazil, the legal use of MFD is only to treat diseases and disorders. This medication belongs to the List A3 of psychotropic drugs dependent on special control, and its acquisition is conditioned to the special yellow recipe and retention of the prescription in the pharmacy at the time of sale (FARIA, 2017).

\section{GOALS}

Describe the main pharmaceutical characteristics of MFD. Highlight the clinical indications for the use of MFD. Detail the possible adverse events arising from the consumption of MFD.

\section{METHODS}

The references used were obtained by research in the databases: Science Research.com, SciELO, LILACS, PubMed, EMBASE, Institutional Repository of the Federal University of São Paulo, Institutional Repository of the Federal University of Minas Gerais and Institutional Repository of the Federal University of Ceará, using the following keywords and associations: "methylphenidate", "ritalin", "effects" and "effects".

The method for selecting the papers was: Identification, Screening, Eligibility and Inclusion. To be included in this review, the studies had to have a complete text RC: 84390 Link di accesso: https://www.nucleodoconhecimento.com.br/salute/metilfenidato-unarecensione 
accessible in the databases surveyed, with relevant content regarding the MFD, as well as being available in any of the following languages: Portuguese, English or Spanish. Exclusively in the PubMed platform, a temporal filter was used in which the publications of the last 5 years were used, in addition to using works related to humans.

The identification was the end of the meeting of studies existing in the literature about MFD in the databases. The screening was done after a quick analysis of the title and abstract of the publications, raising these studies to the category of eligible. In the end, all eligible works were fully read and consequent exclusion of those that were not aligned with the objectives of this review and were perhaps not excluded in the previous stages. Finally, the approved ones were included in all previous stages of the applied method.

\section{RESULTATS}

Research on MFD in the databases resulted in 1038 articles in the methodological stage of identification. When screening, 981 were excluded, since only $5.49 \%$ of the studies were eligible. Finally, with the full reading of all eligible, 37 papers were included, and $35.09 \%$ of the eligible ones were discarded.

\section{MFD PHARMACOLOGY}

The MFD, whose IUPAC (International Union of Pure and Applied Chemistry) nomenclature is Methyl 2-phenyl-2(piperidil) acetatate, has two chiral carbons and chemical formula $\mathrm{C}_{14} \mathrm{H}_{19} \mathrm{NO}_{2}$. It consists of a racemic mixture formed by four stereoisomers, which are d-treo-MFD, $d$-treo-MFD, l-treo-MFD, $d$-eritro-MFD e o leritro-MFD. The pharmacologically active compound is racemate dextrogyl (d,I)-treoMFD, which reacts with dopamine receptors in the striated body and provides noradrenergic stimulation in the cortex (BATISTA, 2015; FREESE et al., 2012; LINHARES, 2012).

MFD is an indirect agonist of dopamine and norepinephrine, intensely influencing the action of these neurotransmitters in motor centers and attention (BATISTA, 2015; RC: 84390 Link di accesso: https://www.nucleodoconhecimento.com.br/salute/metilfenidato-una- 
BATISTELA, 2011). It acts by inhibiting dopamine reuptake by pre-sinaptic neurons of cortical and subcortical regions (FREESE et al., 2012).

\section{THERAPEUTIC APPLICATIONS OF MFD}

MFD is the first-line psychostimulant for the pharmacological approach to ADHD and for the treatment of Narcolepsy, a very rare sleep disorder. It is also used for recreational, aesthetic and cognitive enhanced purposes related to increased school and labor productivity (BARROS; ORTEGA, 2011; BATISTELA, 2011; BRANT; CARVALHO, 2012; CALDEIRA, 2015; CÂNDIDO, 2018; SALVIANO, 2015).

It is reported that the association of MFD with selective serotonin recapture inhibitor (ISRS) was effective in the therapy of symptoms of Gilles de la Tourette's Syndrome (PASSOS; LÓPEZ, 2010), as well as for the treatment of cognitive deficit in a patient who is a victim of traumatic brain injury (TCE) (ROCHA; MALLOY-DINIZ; HARA, 2006).

MFD is also used in adult patients with advanced neoplasms, in order to treat drowsiness due to the use of opioids, depressive symptoms, hypoactive delirium and fatigue due to cancer. There is a description that MFD is a therapeutic alternative for patients diagnosed with Acute Mania (CAMPOS et al., 2016; LÓPEZ-GARCÍA; HEGERL, 2013; PAPA, 2013).

\section{ADVERSE REACTIONS OF MFD USE}

Children and adolescents have as main adverse reactions insomnia and decreased appetite, being directly proportional the doses of MFD ingested, besides presenting xerostomia and irritability. Severe involvement of the psychiatric state may occur, potentiating or causing psychotic disorders or episodes of Mania and Tics. Effects such as abdominal pain and headache are important, as well as a small increase in heart rate (BATISTA, 2015; FARIA 2017; LOUZÃ; MATTOS, 2007; PASTURA; MATTOS, 2004). 
With prolonged use, side effects such as reduction of height and development of chemical dependence in the patient (BRANT; CARVALHO, 2012; PASTURA; MATTOS, 2004). Moreover, it is observed that there may be increases greater than 10 $\mathrm{mmHg}$ in the blood pressure of MFD users (CÂNDIDO, 2018).

A study using animal guinea pigs indicates that acute and chronic administration of MFD harms deoxyribonucleic acid (DNA) in the striated and hippocampus body (SALVIANO, 2015). There are reports that MFD also causes nausea, vomiting decrease in growth and weight rate, arrhythmias, coughs and hallucinations, which are visual and tactile in nature related to insects, reptilils or vermins (BATISTA, 2015). In children and young adults diagnosed with ADHD who use MFD, psychosis occurs in 1 in 660 individuals (MORAN et al., 2019).

Alopecia is reported for the use of MFD (NÚÑES-GARCES; SÁNCHEZ-GAYANGO; ROMERO-PÉREZ, 2018), and that slow-release MFD may be related to the development of the Raynaud Phenomenon, an involvement characterized by excessive vasoconstriction of arterioles that irrigate the skin (OTERO et al., 2012).

Grazina et al. (2018) describe femoral fracture in a girl diagnosed with ADHD treated with MFD, associating the drug as the possible cause. In this study, they point out that the bone density of a child using MFD is different from that which does not use, suggesting that the drug increases the risk of fracture.

In rats, which have histologically human-compatible lung tissue, the administration of MFD caused damage to the pulmonary parenchyma by the destruction of alveolar septa (RAPELLO et al., 2015). MFD can be considered an inducing agent of morphological differentiations in salivary glands of rats (LIMA et al., 2016).

The association of MFD with the development of Systemic Sclerosis is described in patients with suspected autoimmune and vasopathic disease (MERIDOR; LEVY, 2019). There are reports of the case of a patient of four decades of life who underwent bariatric surgery with roux-like laparoscopic gastric bypass who had been using the MFD for about a year, and after two weeks of surgery began to present symptoms of RC: 84390 Link di accesso: https://www.nucleodoconhecimento.com.br/salute/metilfenidato-unarecensione 
MFD toxicity, such as paranoia and auditory hallucinations (LUDVIGSSON; HAENNI, 2016).

\section{DISCUSSION}

\section{MFD OPERATING MECHANISM AND ITS METABOLIZATION}

Although the pharmacological characteristics of MFD are well established, its mechanism of operation is not yet fully understood (BRUNELLI, 2013; LINHARES, 2012).

It is known that MFD acts on the dopaminergic and noradrenergic pathways of the cortical and subcortical regions of the brain, mainly in the striated body, binding to dopamine and norepinephrine transporters, blocking them. The result is a greater availability of these in local synaptic cracks, which generates excitatory effects that reflect on the benefits promoted by the MFD (BATISTELA, 2011; BRUNELLI, 2013; CÂNDIDO, 2018; FERNÁNDEZ, 2018; PALHARES, 2015; SALVIANO, 2015).

The main established dopamine transporters are DAT1 and DRD4. There is a report in the literature that some mutations in the genes encoding these transporters are associated with increased response to MFD, a response that is also linked to social and clinical factors (BATISTA, 2015).

The increase in the level of dopamine due to the drug occurs in areas of the CNS, which are susceptible to the action of drugs of abuse (FARIA, 2017).

Norepinephrine has NAT as a transporter, which is the primary mechanism of dopaminergic pathway inactivation. When blocked, it raises the pre-sinaptitic levels of Norepinephrine, resulting in greater activation of the noradrenegy pathway (LINHARES, 2012).

Dopamine acts directly in the modulation of cognitive and motor functions, memory consolidation, attention promotion, in addition to the processing of some environmental information of paramount importance for survival, performing these functions, in part, $\mathrm{RC}: 84390$ Link di accesso: https://www.nucleodoconhecimento.com.br/salute/metilfenidato-una- 
on the D1 (excitatory function) and D2 (inhibiting function) receptors of the prefrontal cortex. Therefore, it is assumed that the deficit in its function causes the appearance of inattention and hyperactivity, two clinical signs compatible with the picture of ADHD (BATISTELA, 2011; LIANG et al., 2018; LINHARES, 2012; OCHI; VIEIRA, 2016).

In relation to Norepinephrine, it is known that it acts in areas that influence behavioral inhibition stimuli. Thus, it is infers that the deficit in its function can lead to the inability to control impulses, another characteristic of ADHD (LIANG et al., 2018; LINHARES, 2012; OCHI; VIEIRA, 2016).

There are three MFD formulations available on the market: Ritalin $\AA$, Ritalin LA® and Concerta $L A \Theta$, which vary in relation to the half-life time, release time and duration of action. The first consists of a rapid action formulation, promoting MFD peaks around 1 to 3 hours after ingestion, with a half-life between 2 to 3 hours and duration of action between 3 and 6 hours. The latter two consist of rapid action formulations, which promote MFD peaks around 3 to 4 hours after ingestion, with a half-life of 4 hours and duration of action ranging from 8 to 12 hours. What will differ from them is the amount of doses that can be taken per day: Ritalin LA $®$ can be taken 1 or 2 times a day; La Concerta® 1 time a day (LINHARES, 2012; LOUZÃ; MATTOS, 2007; PAPA, 2013).

The absorption of MFD occurs completely, and can easily cross the hematocephalic barrier due to its liposolubility (LINHARES, 2012).

Around 48 to 96 hours, MPH is metabolized by the hepatic microsomal system, by a hydrolysis process that generates ritalin acid, substrate eliminated from the body by urinary excretion. The remainder of the drug that is not metabolized will be eliminated along with bile secretion (LINHARES, 2012; PAPA, 2013).

The metabolization of MFD in the liver occurs by the action of carboxylesterases (CES) - mainly CES1. Mutations in the gene encoding the enzyme are linked to a deficit in the metabolism of the drug, susceptible the user to the development of adverse reactions (BATISTA, 2015). 


\section{SAFETY OF USE}

Because it is an amphetamine derivative, MFD instigates several discussions in the literature about the ability of this drug to cause chemical dependence and excessive use in users, which is still controversial. The rarity of cases of chemical dependence and abuse suggest a low risk on the part of Methylphenidate (BRANT; CARVALHO, 2012; FERNÁNDEZ, 2018; PALHARES, 2015; PASTURA; MATTOS, 2004).

It is recommended that the possible existence of emotional instability in the patient be evaluated before prescribing the MFD, which is due to the risk that these individuals have of increasing the doses of the medication spontaneously (BRANT; CARVALHO, 2012).

Individuals who have previously had comorbidities such as systemic arterial hypertension, cardiac arrhythmias, depression, epilepsy, and bipolar disorder should be treated with caution regarding the use of MFD. In the first two cases, patients should be monitored over time to detect possible complications. In the third case, mfd is possible with antidepressant medications. In the last two cases, it is reported that there is safety regarding the use of MFD, provided that the patient has his clinical condition stabilized and properly treated (LOUZÃ; MATTOS, 2007).

Among the available formulations of the medication, the formulation of prolonged release (Concerta $\AA$ ), besides being the most practical, because it has a longer duration, is also the safest, since it prevents the occurrence of harmful effects arising from the sudden increase in methylphenidate levels in the body, without losing its effectiveness (FARIA, 2017; LOUZÃ; MATTOS, 2007; PAPA, 2013).

Although MFD is included by Brazilian legislation in the A3 list of psychotropic substances, Methylphenidate does not have the same pharmacotoxicity as the other substances in this group (methamphetamine, phencyclidin, dronabinol, among others), which gives it greater safety of use (CARLINI et al., 2003). 


\section{MFD CONSUMPTION}

Since the third decade of the 20th century, the class of amphetamine-derived drugs has aroused interest from pharmaceutical industries for the treatment of behavioral disorders, in view of its ability to stimulate the CNS (CÂNDIDO, 2018; FERNÁNDEZ, 2018).

The MFD was synthesized in 1944 by Leandro Panizzon and in 1954 was patented under the name Ritalin (CÂNDIDO et al., 2019). Even with its existence, until then it was not known that its use could bring improvements to the picture of ADHD. This was only established in the 1960s and 1970s when studies proved benefits for children with behavior disorder (BRANT; CARVALHO, 2012; GONÇALVES; PEDRO, 2018).

Despite this, MFD consumption was already established on a large scale worldwide, being used to treat chronic fatigue and narcolepsy, besides being used for weight loss, improvement of athletic performance and intellectual performance (BRANT; CARVALHO, 2012; BRUNELLI, 2013). According to Barros and Ortega (2011), nontherapeutic uses are called recreational, when used to improve wakefulness time and the willingness to practice leisure, aesthetic activities, when used for weight loss, and cognitive enhancement.

In the 1960s, by verifying the improvement of the clinical picture of ADHD with the administration of MFD, the scientific community came to a consensus on the use of the drug to diagnose this disorder, which was initially established for children, but which, as more studies were developed, became effective also for adolescents and adults. If the individual with suspected ADHD presented improvement after the use of the MFD, it was assumed that he had the disease (BRUNELLI, 2013; GONÇALVES; PEDRO, 2018). This aspect, together with the expansion of the criteria for the diagnosis of $A D H D$ and consequent increase in the incidence of ADHD, have contributed to the exacerbation of its consumption in recent years (GONÇALVES; PEDRO, 2018; SALVIANO, 2015). 
However, what draws most attention in the current scenario is the appropriation of the consumption of MFD for non-therapeutic purposes, mainly by individuals over 19 years of age, especially students, student contests, executives, entrepreneurs and health professionals as the main users, being the main motivation to seek higher performance during their activities (BRANT; CARVALHO, 2012; CALIMAN; RODRIGUES, 2014; CÂNDIDO et al., 2019; GONÇALVES; PEDRO, 2018; MORGAN et al., 2017; SALVIANO, 2015).

It is worth highlighting the increase in consumption among adolescents, for use related to decreased appetite and tiredness, in addition to neuroenhancement (CÂNDIDO et al., 2019; GONÇALVES; PEDRO, 2018; SALVIANO, 2015). The study conducted by Cândido et al. (2019) found that of the students evaluated who used methylphenidate for neuroenhancement, about one third of them acquired the drug without a prescription. The same authors call attention to the need for intervention on this practice, since there is a lack of proof of the effectiveness of the MFD for this purpose.

\section{DOSAGE OF MFD AND ITS RELATIONSHIP WITH THE ADVERSE EFFECTS OF THE DRUG}

Some studies show that the development of adverse effects due to the use of MFD, such as insomnia and decreased appetite, is conditioned by the dosage administered, and these events may go back over time or with decreased dosage (BATISTA, 2015; BATISTELA, 2011; LOUZ̃̃; MATTOS, 2007; PASTURA; MATTOS, 2004).

Holmskov et al. (2017), based on a study on gastrointestinal adverse events during treatment with methylphenidate, found no differences in the risk of adverse effects when considered dose, type or duration of administration.

A low frequency of development of adverse effects in users of the drug is contacted, and in most cases they are mild or moderate (SALVIANO, 2015).

In the case of children, treatment for ADHD is done with dosages of 5 to $20 \mathrm{mg} /$ day, with adjustments as needed (FARIA, 2017). 
Papa ${ }^{1}$ points out that no cardiovascular changes are found with dosages below $30 \mathrm{mg}$. This is important for the therapy of the disease, since there are reports of cardiovascular alterations with the use of MFD (FARIA, 2017; HENNISSEN et al., 2017; SALVIANO, 2015).

To alleviate the discomforts generated by some adverse effects, there are recommendations to be followed: to discontinue the use of MFD with the emergence of any adverse events, in order to verify whether the drug was the causative agent. In cases of worsening coincident with the peak levels of MFD in the body, it can be proposed the use of the long-release formulation. In insomnia, avoiding the use of MFD close to bedtime, increasing the dosage in the morning and decreasing at night, are measures that are effective. For loss of appetite, the patient can opt for the short-action formulation, in order to manage the time of action of the drug and, consequently, the side effect promoted by it (PASTURA; MATTOS, 2004).

\section{CONCLUSÃO}

The effects of MFD stem from inhibition of neurotransmitter receptors such as dopamine and norepinephrine in cortical and subcortical regions related to motor control and attention. With this inhibition, the neurotransmitters are in greater amount of the synaptic cleft, causing the effects of the drug.

MFD can generate chemical dependence, as it is derived from amphetamines, but in the literature there are few cases of dependence arising from its use.

MFD is indicated for patients diagnosed with ADHD, but can also be used for other purposes, including the treatment of narcolepsy, cognitive enhancement, recreation, aesthetics, an alternative approach to acute mania, and treatment of symptoms of patients with advanced neoplasms.

The use of MFD can cause side effects, the main ones of which are insomnia and lack of appetite, and these effects are directly proportional to the doses ingested. 
The literature shows that MFD is efficient in the treatment of ADHD, but does not make clear if it causes dependence, nor is it negatively influenced on children's growth and weight gain.

\section{REFERENCES}

BARROS, D.; ORTEGA, F. Metilfenidato e Aprimoramento Cognitivo Farmacológico: representações sociais de universitários. Saúde Soc, v. 20, n. 2, p. 350-63, 2011.

BATISTA, J. M. N. Estudo farmacoterapêutico e farmacogenético em crianças e adolescentes com transtorno do déficit de atenção e hiperatividade tratados com metilfenidato. Tese de Doutorado - Universidade de Federal do Ceará. Fortaleza, p. 95. 2015.

BATISTELA, S. Efeitos da administração aguda de diferentes doses do metilfenidato sobre a cognição de jovens saudáveis. Tese (Mestre em Ciências) - Universidade Federal de São Paulo. São Paulo, p. 88. 2011.

BRANT, L. C.; CARVALHO, T. R. F. Metilfenidato: medicamento gadget da contemporaneidade. Interface comun saúde educ, v. 16, n. 42, p. 623-36, 2012.

BRUNELLI, L. F. O Metilfenidato (RITALINA®) na escola: Percepção dos educadores da rede de Ensino fundamental I e II. Dissertação (Mestrado em Ciências Humanas e Sociais Aplicadas) Universidade Federal de Minas Gerais. Belo Horizonte, p. 100. 2013.

CALDEIRA, C. M. P. Frequência do transtorno de déficit de atenção e hiperatividade (TDAH) e os problemas psicológicos associados em crianças e adolescentes. Monografia (Especialista em Neurociências) - Universidade de Federal do Ceará. Fortaleza. p. 64. 2015.

CALIMAN, L. V.; DOMITROVIC, N. Uma análise da dispensa pública do metilfenidato no Brasil: o caso do Espírito Santo. Physis, v. 23, n. 3, p. 879-902, 2013. 
CALIMAN, L. V.; RODRIGUES, P. H. P. A experiência do uso de metilfenidato em adultos diagnosticados com TDAH. Psicol estud, v. 19, n. 1, p. 125-134, 2014.

CAMPOS, M. P. O. et al. Fadiga relacionada ao câncer: uma revisão. Rev Assoc Med Bras, v. 57, n. 2, p. 211-219, 2016.

CÂNDIDO, R. C. F. Metilfenidato de liberação imediata para o transtorno do déficit de atenção e hiperatividade (TDAH) em adultos - revisão sistemática. Dissertação (Mestrado em Medicamentos e Assistência Farmacêutica) - Universidade Federal de Minas Gerais. Belo Horizonte, p. 147. 2018.

CÂNDIDO, R. C. F. et al. Perini E, Pádua CM, Junqueira DR. Prevalência e fatores associados ao uso de metilfenidato para neuroaprimoramento farmacológico entre estudantes universitários. Psicol conoc Soc, v. 18, p. 1-7, 2019.

CARLINI, E. A. et al. Metilfenidato: influência da notificação de receita A (cor amarela) sobre a prática de prescrição por médicos brasileiros. Rev Psiquiatr Clín, v. 30, n. 1, p. 11-20, 2003.

FARIA, J. C. M. Desempenho acadêmico de estudantes com diagnóstico de transtorno do déficit de atenção e hiperatividade (TDAH) em uso de metilfenidato - revisão sistemática. Dissertação (Mestrado em Medicamentos e Assistência Farmacêutica) - Universidade Federal de Minas Gerais. Belo Horizonte, p. 77.2017.

FERNÁNDEZ, L. C. S. Psicoestimulantes para el TDAH: análisis integral para una medicina basada en la prudencia. Rev Asoc Esp Neuropsiq, v. 38, n. 133, p. 301330. 2018.

FREESE, L. et al. Uso não médico de metilfenidato: uma revisão. Trends psychiatry psychother, v 34, n. 2, p. 110-115, 2012. 
GONÇALVES, C. S.; PEDRO, R. M. L. R. "Drogas da Inteligência?”: Cartografando as controvérsias do consumo da Ritalina para o aprimoramento cognitivo. Psicol conoc Soc, v. 8, n. 2, p 71-94, 2018.

GRAZINA, R. et al. Fractura por estrés del cuello del fémur en unaniña hiperactiva tratada con metilfenidato - Reporte de caso. Rev Asoc Argent Ortop Traumatol, v. 83 , n. 1, p. 45-49, mar. 2018.

HENNISSEN, L. et al. Cardiovascular Effects of Stimulant and Non-Stimulant Medication for Children and Adolescents with ADHD: A Systematic Review and MetaAnalysis of Trials of Methylphenidate, Amphetamines and Atomoxetine. CNS drugs, v. 31, n. 3, p. 199-215, 2017.

HOLMSKOV, M. et al. Gastrointestinal adverse events during methylphenidate treatment of children and adolescents with attention déficit hyperactivity disorder: A systematic review with meta-analysis and Trial Sequential Analysis of randomised clinical trials. PLos ONE, v. 12, n. 6, p. 1-18, 2017.

LIANG, E. F. et al. The Effect of Methylphenidate and Atomoxetine on Heart Rate and Systolic Blood Pressure in Young People and Adults with Attention-Deficit Hyperactivity Disorder (ADHD): Systematic Review, Meta-Analysis, and MetaRegression. Int J Environ Res Health Public, v. 17, n. 1789, p 1-16, 2018.

LIMA, K. S. et al. Efeitos do metilfenidato sobre as glândulas salivares maternas de camundongos. Rev Odontol UNESP, v. 45, n. 6, p. 316-321, 2016.

LINHARES, M. I. Estudo da Ritalina ${ }^{\circledR}$ (cloridrato de metilfenidato) sobre o sistema nervoso central de animais jovens e adultos: aspectos comportamentais e neuroquímicos. Dissertação (Mestrado em Farmacologia) Universidade Federal do Ceará. Fortaleza, p. 145. 2012.

LÓPEZ-GARCÍA, P.; HEGERL, U. Tratamiento de la manía aguda com metilfenidato: propuesta terapêutica basada en un nuevo modelo fisiopatológico. Rev psiquiatr salud ment, v. 6, n. 2, p. 93-94, 2013. 
LOUZÃ, M. R.; MATTOS, P. Questões atuais no tratamento farmacológico do TDAH em adultos com metilfenidato. J bras psiquiatr, v. 56, n. 1, p. 53-56, 2007.

LUDVIGSSON, M.; HAENNI, A. Methylphenidate toxicity after Roux-en-Y gastric bypass. Surg Obes Relat Dis, v. 12, n. 5, p. 55-57, 2016.

MERIDOR, K.; LEVY, Y. Systemic sclerosis induced by CNS stimulants for ADHD: A case series and review of the literature. Autoimmun Rev, v. 19, n. 1, p. 1-3, 2019.

MORAN, L. V. et al. Psychosis with Methylphenidate or Amphetamine in Patients with ADHD. N Engl J Med, v. 380, n. 12, p. 1128-1138, 2019.

MORGAN, H. L. et al. Consumo de Estimulantes Cerebrais por Estudantes de Medicina de uma Universidade do Extremo Sul do Brasil: Prevalência, Motivação e Efeitos Percebidos. Rev bras educ med, v. 41, n. 1, p. 102-109, 2017.

NÚÑES-GARCES, M.; SÁNCHEZ-GAYANGO, A.; ROMERO-PÉREZ, C. Alopecia reversible secundaria a metilfenidato OROS. Rev colomb psiquiatr. 2018. DOI: 10.1016/j.rcp.2018.09.003.

OCHI, N. O.; VIEIRA, G. L. Efeitos do metilfenidato no desempenho motor de crianças com TDAH. Revista Saúde e Pesquisa, v. 9, n. 1, p. 93-96, 2016.

OTERO, M. I. et al. Metilfenidato y fenómeno de Raynaud secundario. Semergen, v. 39 , n. 6, p. 330-334, 2012.

PALHARES, J. P. P. "Eu tomo medicamentos para estudar": compreendendo a experiência com metilfenidato entre estudantes universitários. Dissertação (Mestrado em Medicamentos e Assistência Farmacêutica - Universidade de Federal de Minas Gerais. Belo Horizonte, p. 86. 2015.

PAPA, M. P. Uso del metilfenidato en pacientes con cáncer avanzado. Rev Med Urug, v. 29 , n. 1 , p. $58-63,2013$. 
PASSOS, R. B. F.; LÓPEZ, J. R. R. A. Síndrome de Gilles de la Tourette associada ao transtorno de déficit de atenção com hiperatividade: resposta clínica satisfatória a inibidor seletivo da recaptura de serotonina e metilfenidato. J bras psiquiatr, v. 59, n. 2, p. 160-162, 2010.

PASTURA, G; MATTOS, P. Efeitos colaterais do Metilfenidato. Revista de Psiquiatria Clínica, v. 31, n. 2, p. 100-104, 2004.

RAPELLO, G. V. G. et al. Pulmonary emphysema induced by methylphenidate: experimental study. Sao Paulo Med J, v. 133, n. 2, p. 131-134, 2015.

ROCHA, F. L.; MALLOY-DINIZ, L. F.; HARA, C. Emprego de metilfenidato para o tratamento de déficit cognitivo em paciente com seqüela de traumatismo cranioencefálico. J bras psiquiatr, v. 55, n. 1, p. 78-81, 2006.

SALVIANO, L. H. M. S. Estudo de segurança da Ritalina® (cloridrato de metilfenidato) em animais adultos: aspectos de neurotoxicidade e nefrotoxicidade. Tese de doutorado - Universidade de Federal do Ceará, Fortaleza, p. 149.2015.

Submitted: May, 2021.

Approved: May, 2021. 